\title{
Magnesium Administration For COPD Exacerbation: A Systematic Review and Meta-analysis
}

\author{
Hala Alzaid, Fay Aldossari, and Sharafaldeen Bin Nafisah
}

\begin{abstract}
BACKGROUND: The role of magnesium in patients with acute chronic obstructive pulmonary disease (COPD) exacerbation remains to be determined.

AIM: We aim to explore the effect of magnesium on COPD exacerbation, as well as its impact on pulmonary function tests and on hospital admissions for acute exacerbation in the emergency department.

METHODS: This is a systematic review and meta-analysis that included a search of the keywords "magnesium" and "COPD" on PubMed, Google Scholar, Cochrane databases, and Gray literature (ClinicalTrials.gov and World Health International Clinical Trials Registry Platform) from 1963 to May 2021.

RESULTS: The use of IV magnesium reduced the risk ratio for admission $R R=0.85$ (95\% CI 0.62 to 1.17$)$. The combined risk ratio for admission increased to 0.95 when we added nebulised magnesium sulphate $(95 \%$ CI 0.85 to 1.07$), p>0.05$. The mean score for improvement after IV magnesium was higher $(M=16.75$, $\mathrm{SD}=5.11)$ than the mean score before its administration $(M=8.74$, $\mathrm{SD}=8.85), \mathrm{t}(4)=-2.57, \mathrm{p}=\mathbf{0 . 0 3 1}$. Thus, the use of IV magnesium sulphate results in a $91.64 \%$ improvement in the pulmonary function test.

CONCLUSION: IV magnesium sulphate improves the pulmonary function test of patients with acute COPD exacerbation in the ED, and possibly reduces the admission rate.
\end{abstract}

Index Terms-Magnesium for COPD, COPD exacerbation

\section{INTRODUCTION}

Magnesium was first used as a bronchodilator in 19361940 by Rossello and Pia, and Haury [1, 2]. A calcium antagonist that inhibits smooth-muscle contraction was the postulated mechanism [3]; the bronchodilatory effect was also attributed to interference with parasympathetic stimulation and potentiating the effect of $\beta 2$-agonists $[4,5]$. Other proposed mechanisms include blocking histamine release from mast cells [6] and inhibiting acetylcholine release [7], as well as its sedative action [8].

Extensive studies have explored the efficacy of magnesium in asthma exacerbation. Those studies revealed improvement in lung function tests [9], reducing the need for hospital admission and mechanical ventilation [10,11]. Nonetheless, the effect of magnesium on COPD needs further elucidation. Magnesium's bronchodilatory effects have been advocated for acute exacerbation of COPD [12]. Furthermore, it has been noted that pulmonary function might improve in the

Hala Alzaid, Fay Aldossari, Sharafaldeen Bin Nafisah are with Emergency Department, King Fahad Medical City, Saudi Arabia, email: Halaa.z@hotmail.com, e-mail: dr.faay@gmail.com, e-mail: dr.sharafaldeen@yahoo.com

Fay Aldossari is the corresponding author. short term with the use of IV magnesium [13]. The use of nebulised magnesium, on the other hand, has revealed mixed results - hampering a solid conclusion $[14,15]$. Thus, the dose, the route, and when to administer magnesium remain unclear. This study aims to explore the effect of magnesium on COPD exacerbation; we also aim to explore its impact on pulmonary function tests and on hospital admissions for acute exacerbation in the emergency department.

\section{METHODS}

Search strategy:

We searched PubMed, Google Scholar, Cochrane databases, and Gray literature (ClinicalTrials.gov and World Health Organization International Clinical Trials Registry Platform). We also explored the reference lists of included articles, and any systematic reviews and meta-analyses identified therein. We searched the keywords "magnesium" and "COPD", from 1963 to May 2021.

\section{Selection criteria:}

Our inclusion criteria were all articles that measured the effect of magnesium sulphate on patients with COPD. We excluded non-English articles that lacked translation; articles investigating the effect of magnesium on patients not in exacerbation; articles involving the use of magnesium beyond the ED course of stay (e.g., after admission); and finally, studies in which patients received adjunct management that deviates from the current standard of care, i.e. inhaled bronchodilator, anticholinergic, oxygen and possible antibiotic.

\section{Data extraction, quality assessment, and qualitative synthe-} sis:

The studies' eligibility for inclusion was examined by two independent researchers; a third researcher was approached in the event of any disagreement regarding a study's inclusion.

We used the RoB 2 Cochrane risk-of-bias tools for randomised controlled trials to assess the studies' bias [16]. Data analysis was conducted with the use Review Manager Web [17], using a random-effects model, on the assumption that the studies included would be weighted more equally in cases of possible heterogeneity [18]. We also used a paired ttest to measure the mean effect of magnesium sulphate on the pulmonary function test. The analysis was recorded in accordance with the Preferred Reporting Items for a Review and Meta-analysis of Individual Participant Data [19]. The study approved by the IRB committee with an IRB log number of 21-259. 


\section{Outcomes:}

The primary outcome was the effect of magnesium sulphate on admission rates in patients with acute COPD exacerbation. The secondary outcome was the effect of magnesium sulphate on the pulmonary function test.

\section{RESULTS}

Study selection:

19,100 articles were identified, as illustrated in the Prisma chart (Figure 1). We were unable to retrieve one article, and six had no translation. We also excluded two articles targeting COPD patients not in exacerbation, and two articles in which intervention was provided after the patients were admitted, including a trail which deviated from usual practice [20]. The three included randomised controlled trials are illustrated in Table 1; Table 2 describes the risk of bias in those studies. Two of the included studies used intravenous magnesium sulphate, while one used nebulised magnesium sulphate; there was a total of 211 patients across the three studies (97 cases comprising $45.97 \%$, and 114 in the control group; 54.03\%). The three studies reported a primary outcome of improved peak expiratory flow (PEF), forced expiratory volume (FEV1) and forced vital capacity (FVC), with a secondary outcome of admission to the hospital.

\section{Demographic characteristics:}

Table 3. illustrates the demographic characteristics of the population in the included studies. The patients included in the studies were of similar mean age, while there were fewer females in the intervention group. In addition, the heart rate, respiratory rate and serum magnesium levels were similar between the two groups. However, due to the reporting inconsistencies, other variables - including history of smoking, oral steroid use, at-home use of oxygen and other pertinent medical history - could not be assessed.

The effect of magnesium administration on the admission rate:

Two studies examined the effect of IV magnesium sulphate on the admission rate, with 49 patients in the intervention group and 53 in the control group. A funnel plot revealed no evidence of publication bias, as illustrated in Figure 2. A forest plot revealed no evidence of heterogeneity across the two trials $\left(\mathrm{I}^{2}=17 \%, \mathrm{~T}^{2}=0.01, \mathrm{p}>0.05\right)$. The combined risk ratio for admission was 0.85 (95\% CI 0.62 to 1.17$)$. The forest plot is illustrated in Figure 3.

Combining the nebulised magnesium sulphate with the IV magnesium sulphate studies did not result in significant heterogeneity $\left(\mathrm{I}^{2}=2 \%, \mathrm{~T}^{2}=0.00, \mathrm{p}>0.05\right)$, as illustrated in Figure 4. However, the combined risk ratio for admission increased to 0.95 compared with that of only IV magnesium sulphate $(95 \%$ CI 0.85 to 1.07$)$.

The effect of magnesium administration on the pulmonary function test:

The effect of IV magnesium sulphate was measured using PEF (measured in L/min) in one of the studies [12], while the second study [13] used FVC (measured in $\mathrm{mL}$ ), as shown in Figures 5 and 6 , respectively.
The effect of nebulised magnesium sulphate was measured using FEV1 (measured in $\mathrm{mL}$ ) [14], as shown in Figure 7. The use of different units of measurement in the three studies precluded a meta-analysis.

Due to the different outcome measures, we calculated the percentage difference in improvement between the intervention group and the placebo group. We then explored the effect of IV magnesium sulphate using a pre-and post-analysis, standardising the unit of measurement to percent change. We noted a significant difference; the mean score for improvement after IV magnesium was higher $(\mathrm{M}=16.75, \quad \mathrm{SD}=5.11)$ than the mean score before its administration $(\mathrm{M}=8.74, \mathrm{SD}=8.85)$, $t(4)=-2.57, p=0.031$. Thus, the use of IV magnesium sulphate results in a $91.64 \%$ improvement in the pulmonary function test.

\section{DISCUSSION}

The effectiveness of magnesium has been investigated extensively in patients with bronchial asthma, but not for acute COPD exacerbation, despite a similar advocated mechanism of action [21, 22]. Our analysis builds on previous studies that failed to demonstrate a reduction in admission rates and revealed minimal improvement on the pulmonary function test [23]. When using IV magnesium sulphate, the admission rate might have been reduced by $38 \%$, or increased to $17 \%$, with an overall estimate toward reduced admission. When we included nebulized magnesium sulphate, the estimate was toward reduced admission by $15 \%$ with possible increased by $7 \%$; however, the total estimates showed a RR of 0.95 which is less than for IV magnesium sulphate alone. Although the results were not statistically significant and type II error might prevail.

A previous analysis reported an increased risk of readmission in patients with lower magnesium levels [24]. Since the patients in this review had normal serum magnesium levels, we argue that the positive impact of magnesium on the admission rate is also related to its bronchodilatory effect, rather than only to raising serum levels. Perhaps the most important determinant for admission is respiratory distress, which is best addressed by bronchodilatory medications [25]. Further studies are needed to support or refute such a claim.

Furthermore, we noted an improvement in pulmonary function tests with the use of IV magnesium sulphate. This improvement was noted in PEF and FVC. These findings align with a previous analysis which found that magnesium positively affected respiratory muscle strength and hyperinflation, even in stable COPD patients [26].

It is prudent to assert that we demonstrated a positive effect of magnesium on the pulmonary function tests of patients with normal magnesium levels. Although the improvement in pulmonary function tests has previously been attributed to the correction of hypomagnesaemia [1], nonetheless, we demonstrated an improvement despite normal serum magnesium levels.

Congruent with a previous systematic review [23], the use of nebulised magnesium does not reduce the admission rate or improve the pulmonary function tests. On the contrary, 
Table 1. Studies included in our analysis

\begin{tabular}{|c|c|c|c|c|c|}
\hline Study name & Design & Exclusion criteria & $\begin{array}{l}\text { Intervention/ } \\
\text { control }\end{array}$ & $\begin{array}{l}\text { Dose and route } \\
\text { (intervention/ } \\
\text { control) }\end{array}$ & $\begin{array}{l}\text { Sample size } \\
\text { (intervention/ } \\
\text { control) }\end{array}$ \\
\hline $\begin{array}{l}\text { Skorodin et } \\
\text { al. (1995) }\end{array}$ & RCT & $\begin{array}{l}\text { Younger than } 35 \\
\text { years; fever }(> \\
\left.37.9^{\circ} \mathrm{C}\right) ; \\
\text { hypotension } \\
(\text { systolic BP }<100 \\
\text { mmHg); history of } \\
\text { renal disease; } \\
\text { presence of } \\
\text { pneumonia }\end{array}$ & $\begin{array}{l}\text { IV magnesium } \\
\text { sulphate/ normal } \\
\text { saline (after } 20 \mathrm{~min} \\
\text { of nebulised } \\
\text { albuterol) }\end{array}$ & $\begin{array}{l}1.2 \mathrm{~g} \text { in } 150 \mathrm{~mL} \\
\text { normal saline over } \\
20 \mathrm{~min} \text {. (three } \\
\text { patients received } 3 \\
\mathrm{~g}) / 2.4 \mathrm{~mL} \text { saline as } \\
\text { a placebo in } 150 \mathrm{~mL} \\
\text { normal saline }\end{array}$ & $36 / 36$ \\
\hline $\begin{array}{l}\text { Mukerji et } \\
\text { al. (2015) }\end{array}$ & RCT & $\begin{array}{l}\text { Uncooperative } \\
\text { patients, requiring } \\
\text { PPV; pneumothorax } \\
\text { or hypotension }\end{array}$ & $\begin{array}{l}\text { IV magnesium } \\
\text { sulphate/ normal } \\
\text { saline }\end{array}$ & $\begin{array}{l}2 \text { g magnesium } \\
\text { sulphate in normal } \\
\text { saline over } 15 \mathrm{~min} / \\
20 \mathrm{~mL} \text { normal saline }\end{array}$ & $13 / 17$ \\
\hline $\begin{array}{l}\text { Edwards et } \\
\text { al. }(2013)\end{array}$ & RCT & $\begin{array}{l}\text { Uncooperative } \\
\text { patients; younger } \\
\text { than } 35 \text { years; } \\
\text { requiring PPV; } \\
\text { hypotension, } \\
\text { pneumothorax, or } \\
\text { pregnancy. }\end{array}$ & $\begin{array}{l}\text { Nebulised } \\
\text { magnesium } \\
\text { sulphate/ nebulised } \\
\text { isotonic saline }\end{array}$ & $\begin{array}{l}2.5 \mathrm{ml} \text { isotonic } \\
\text { magnesium }(151 \\
\mathrm{mg}) 3 \text { times at } 30- \\
\text { min intervals for one } \\
\text { day / } 2.5 \mathrm{ml} \text { normal } \\
\text { saline }\end{array}$ & $52 / 64$ \\
\hline
\end{tabular}

Table 1. continued

\begin{tabular}{|c|c|c|c|c|}
\hline Study name & Result & $\begin{array}{l}\text { Time of intervention (to } \\
\text { ED or bronchodilator) }\end{array}$ & $\begin{array}{l}\text { Mild/moderate or } \\
\text { severe exacerbation }\end{array}$ & $\begin{array}{l}\text { NIPPV included } \\
\text { or excluded }\end{array}$ \\
\hline $\begin{array}{l}\text { Skorodin et al. } \\
\text { (1995) }\end{array}$ & $\begin{array}{l}\text { PEF increased from } \\
136.7 \pm 69.7 \mathrm{~L} / \mathrm{min} \text { to } \\
162.3 \pm 76.6 \mathrm{~L} / \mathrm{min} \text { at } 30 \\
\mathrm{~min} ; \\
\text { then to } 161.3 \pm 78.7 \mathrm{~L} / \mathrm{min} \\
\text { at } 45 \mathrm{~min} \text {. } \\
\text { No difference in } \\
\text { dyspnoea score, } \\
\text { admission rate, ED visit } \\
\text { within two weeks }\end{array}$ & $\begin{array}{l}\text { Bronchodilator used in first } \\
20 \text { min, followed by } \\
\text { intervention }\end{array}$ & $?$ & $?$ \\
\hline $\begin{array}{l}\text { Mukerji et al. } \\
(2015)\end{array}$ & $\begin{array}{l}\text { FEV improved after } 60 \\
\text { min and } 120 \text { min (no } \\
\text { difference in need for } \\
\text { PPV; admission rate } \\
\text { remained unchanged) }\end{array}$ & $\begin{array}{l}\text { Bronchodilator used in first } \\
20 \text { min, followed by } \\
\text { intervention }\end{array}$ & Severe exacerbation & Excluded \\
\hline $\begin{array}{l}\text { Edwards et al. } \\
(2013)\end{array}$ & $\begin{array}{l}\text { No difference in FEV, } \\
\text { admission rate, need for } \\
\text { PPV }\end{array}$ & $\begin{array}{l}\text { Bronchodilator used in first } \\
20 \text { min, followed by } \\
\text { intervention }\end{array}$ & $?$ & Excluded \\
\hline
\end{tabular}


Table 2. Risk of bias in the included studies

\begin{tabular}{|c|c|c|c|c|c|c|c|}
\hline Inclusion & $\begin{array}{l}\text { Sequence } \\
\text { generation }\end{array}$ & $\begin{array}{l}\text { Allocation } \\
\text { concealment }\end{array}$ & $\begin{array}{l}\text { Blinding of } \\
\text { participants and } \\
\text { personnel }\end{array}$ & $\begin{array}{l}\text { Blinding of } \\
\text { outcome } \\
\text { assessor }\end{array}$ & $\begin{array}{l}\text { Incomplete } \\
\text { outcome data }\end{array}$ & $\begin{array}{l}\text { Selective } \\
\text { outcome } \\
\text { reporting }\end{array}$ & $\begin{array}{l}\text { Other } \\
\text { sources } \\
\text { of bias }\end{array}$ \\
\hline $\begin{array}{l}\text { Skorodin et } \\
\text { al. (1995) }\end{array}$ & + & + & $?$ & $?$ & + & - & + \\
\hline $\begin{array}{l}\text { Mukerji et } \\
\text { al. (2015) }\end{array}$ & + & + & + & + & + & - & + \\
\hline $\begin{array}{l}\text { Edwards et } \\
\text { al. (2013) }\end{array}$ & + & + & + & + & + & - & + \\
\hline
\end{tabular}

+ Low risk of bias; - High risk of bias; ? Unclear

Table 3. Demographic characteristics of the population in the included studies

\begin{tabular}{|l|l|l|}
\hline Demographic & Magnesium sulphate & Placebo \\
\hline Age (Mean) & $70.7(\mathrm{SD}=10.42)$ & $69.63(\mathrm{SD}=0.53)$ \\
\hline Total & $\mathrm{n}=97$ & $\mathrm{n}=114$ \\
\hline Gender & $\mathrm{n}=73(75.2 \%)$ & $\mathrm{n}=76(66.7 \%)$ \\
\hline Male & $\mathrm{n}=24(24.7 \%)$ & $\mathrm{n}=38(33.3 \%)$ \\
\hline Female & $95.4(\mathrm{beats} / \mathrm{min})$ & $99.2(\mathrm{beats} / \mathrm{min})$ \\
\hline Heart rate & $21.2(\mathrm{breaths} / \mathrm{min})$ & $22.4(\mathrm{breaths} / \mathrm{min})$ \\
\hline Respiratory rate & & $0.88(\mathrm{mmol} / \mathrm{L})$ \\
\hline $\begin{array}{l}\text { Serum magnesium } \\
\text { level (mean) }\end{array}$ & $0.87(\mathrm{mmol} / \mathrm{L})$ & \\
\hline
\end{tabular}


PAISM A 2020 flow diagram for new systematic reviews which induded searches of databases and registers only

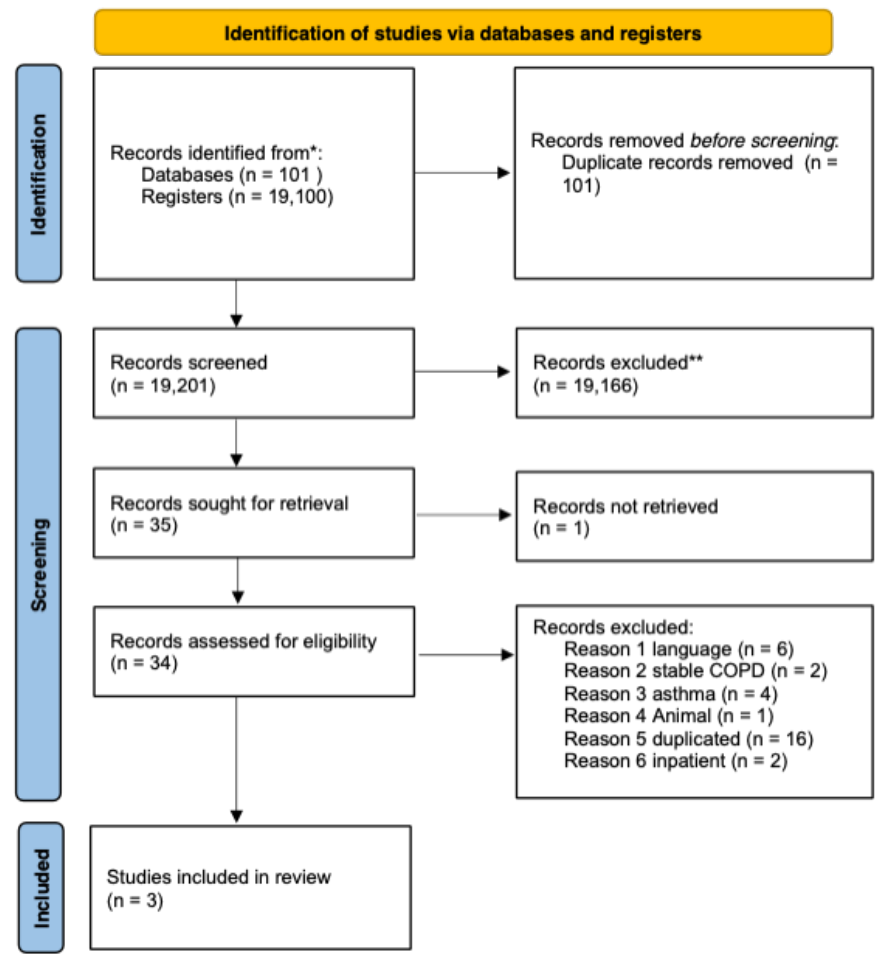

Fig. 1. The Prisma flow chart of the studies identified

we noted that the admission rate increased with the use of nebulised magnesium. However, based on our strict inclusion criteria, we were only able to include one study using nebulised magnesium. This meta-analysis should thus not provide any recommendation on the use of nebulised magnesium in acute COPD exacerbation.

The dose of IV magnesium sulphate that best demonstrates the positive effect varies between $1.2 \mathrm{~g}$, and $3 \mathrm{~g}$. Therefore, it might not be erroneous to infer that the positive effect lies between $1.2-3 \mathrm{~g}$. However, further studies are required to determine the exact dose.

The included articles generally demonstrated low bias. However, several limitations need to be considered. First, we could not infer about the effect of magnesium in patients requiring non-invasive positive-pressure ventilation (NIPPV). Second, the exclusion of those requiring NIPPV might threaten generalisability. Furthermore, uncooperative patients were excluded from two studies; this leaves the question of whether the excluded segment suffered more severe disease than those included. It thus remains unclear as to whether the benevolent effect can be attributed to a specific patient segment.

Overall, we advocate providing IV magnesium sulphate for patients with COPD exacerbation to improve their pulmonary function test and possibly reduce the admission rate. With regard to nebulised magnesium sulphate, however, this analysis was unable to provide a clear recommendation on its use for acute COPD exacerbation. 


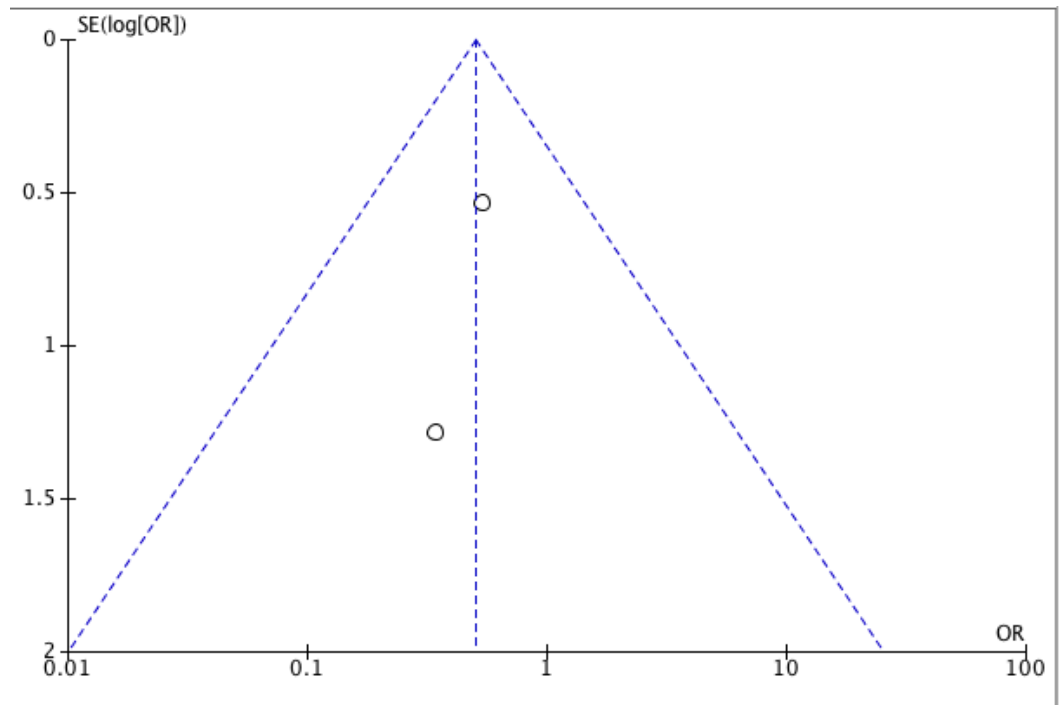

Fig. 2. Funnel plot of the included studies showing symmetrical distribution.

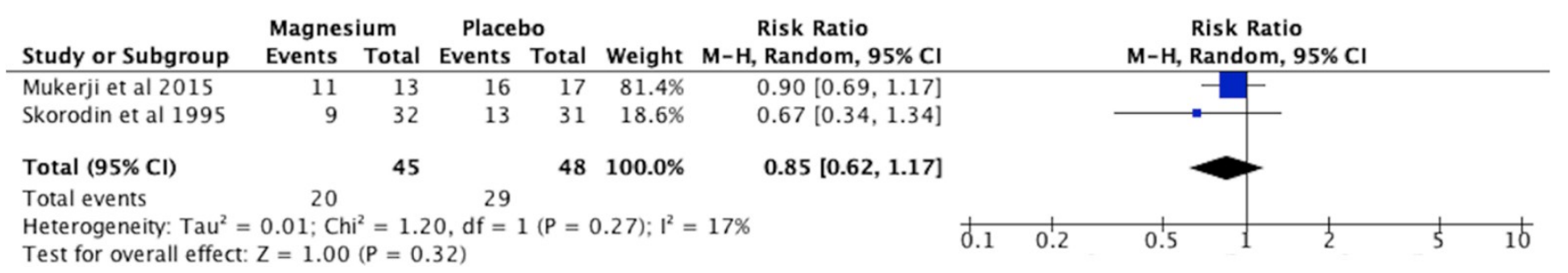

Fig. 3. Forest plot of the effect on the admission rate of IV magnesium sulphate administration in COPD

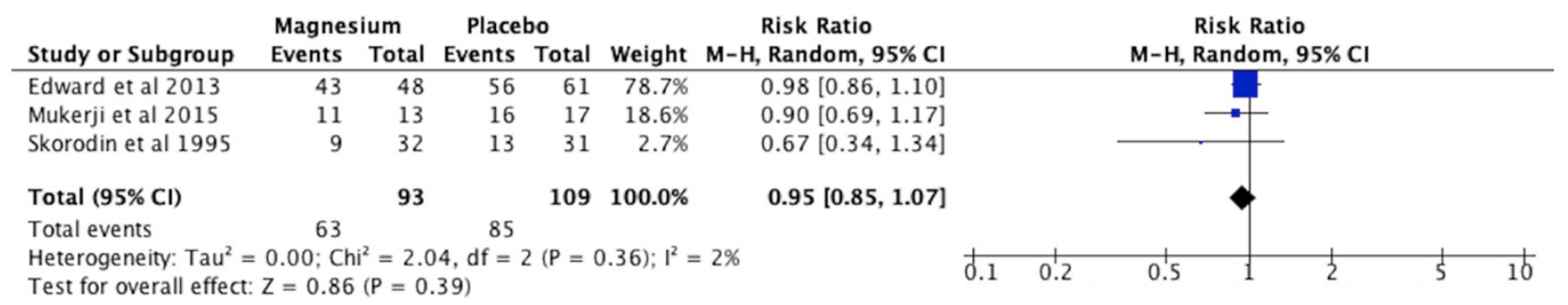

Fig. 4. Forest plot of the combined effects of IV magnesium sulphate with nebulised magnesium.

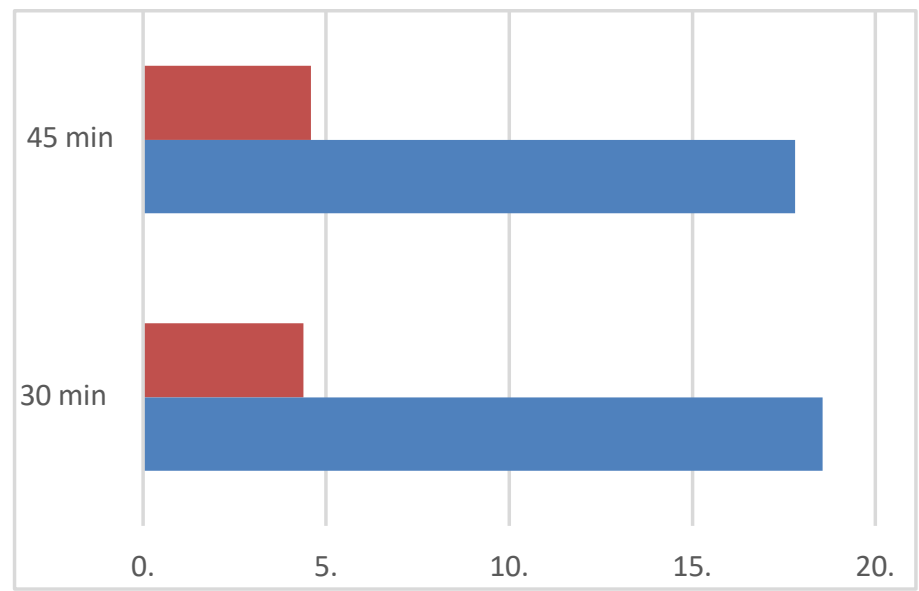

Fig. 5. Bar chart illustrating the effect of IV magnesium sulphate on PEF 


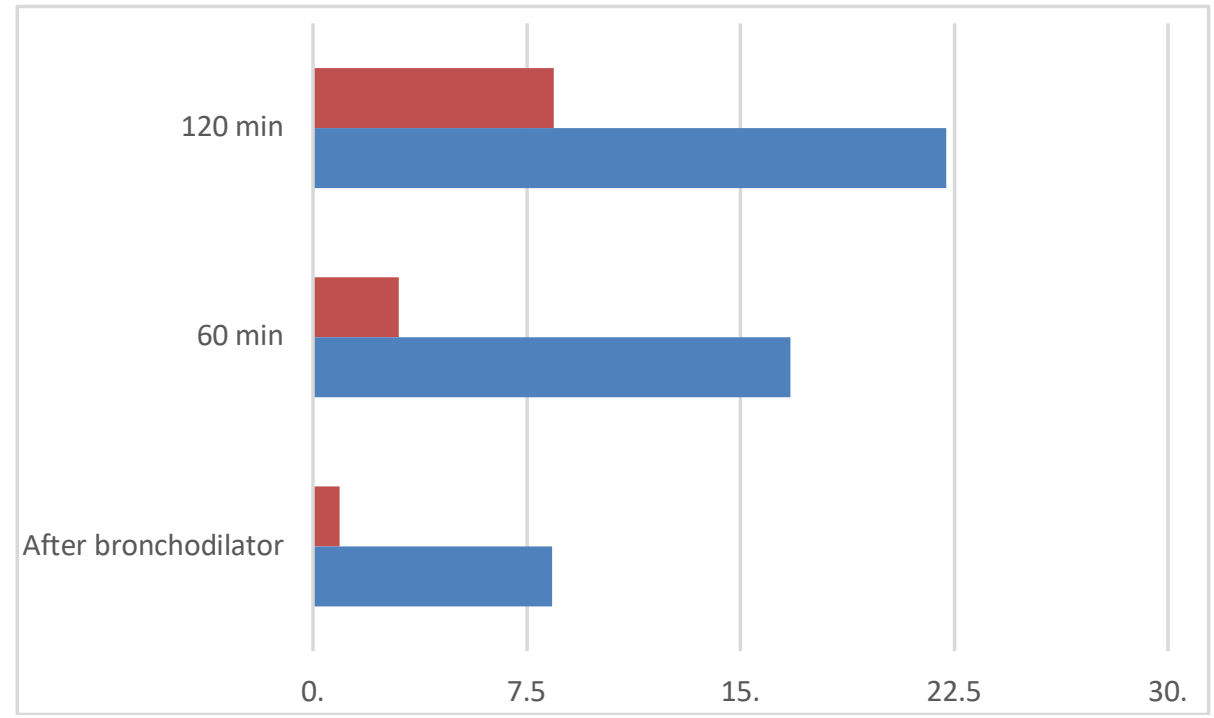

Fig. 6. Bar chart illustrating the effect of IV magnesium sulphate on FVC

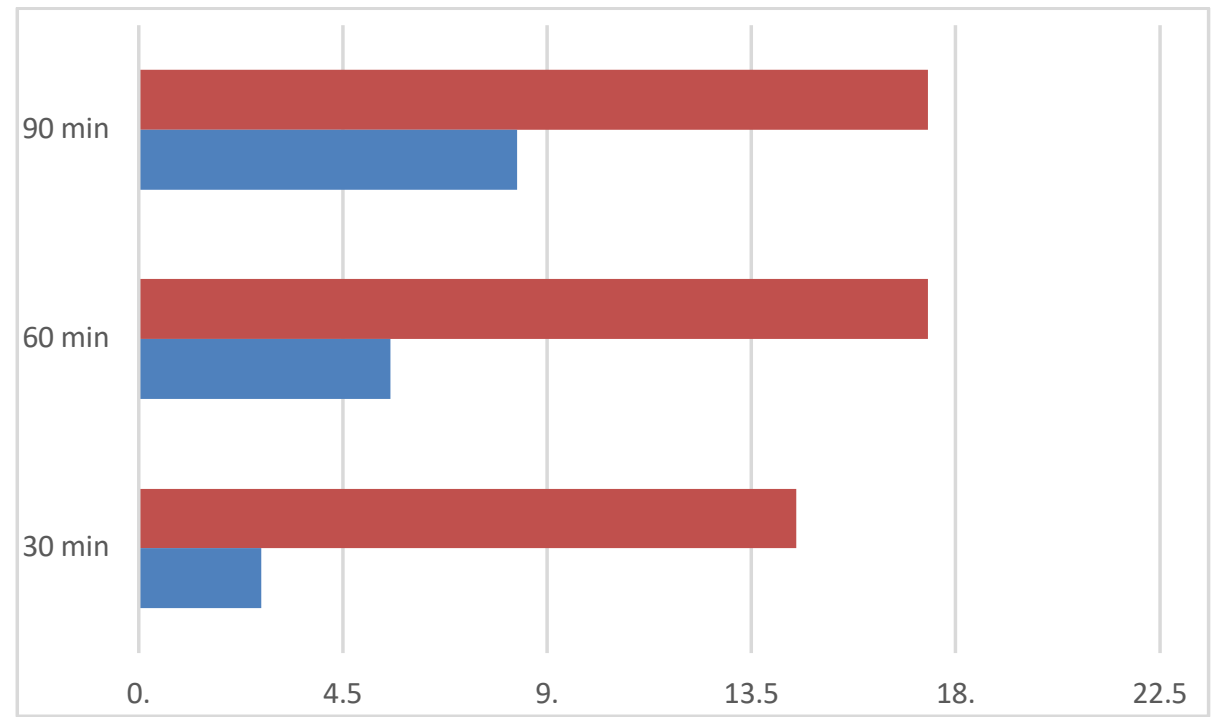

Fig. 7. Bar chart illustrating the effect of nebulised magnesium sulphate on FEV1 


\section{REFERENCES}

[1] Rossello JC, Pla JC. Sulfato de magnesio en la crisis de asma. Prensa Med Argent 1936;23:1677.

[2] Haury VG. Blood serum magnesium in bronchial asthma and its treatment by the administration of magnesium sulphate. J Lab Clin Med 1940; 26:340-341.

[3] Gourgoulianis KI, Chatziparasidis G, Chatziefthimiou A, Molyvdas PA. Magnesium as a relaxing factor of airway smooth muscles. J Aerosol Med. 2001;14:301-307.

[4] Classen HG, Jacob R, Schimatschek H. Interaction of magnesium with direct and indirect-acting sympathomimetic amines. Magnes Bull. 1987;9:80-87.

[5] Noppen M, Vanmaele L, Impens $\mathrm{N}$, et al. Bronchodilating effect of intravenous magnesium sulfate in acute severe bronchial asthma. Chest. 1990;97:373-376.

[6] Bois P. Effect of magnesium deficiency on mast cells and urinary histamine in rats. Br J ExpPathol 1963;44:151-155.

[7] Del Castillo J, Engbaek L. The nature of the neuromuscular block produced by magnesium. J Physiol. 1954;124:370-384.

[8] Wacker WEC, Vllee BL. Magnesium metabolism. N Engl J Med 1958;259:431-438, 452-482.

[9] Alter HJ, Koepsell TD, Hilty WM. Intravenous magnesium as an adjuvant in acute bronchospasm: a metaanalysis. Ann Emerg Med. 2000 Sep;36(3):191-7. doi: 10.1067/mem.2000.109170. PMID: 10969219.

[10] McNamara RM, Spivey WH, Skobeloff E, Jacubowitz S. Intravenous magnesium sulfate in the management of acute respiratory failure complicating asthma. Ann Emerg Med. 1989;18:197-199.

[11] Kew KM, Kirtchuk L, Michell CI. Intravenous magnesium sulfate for treating adults with acute asthma in the emergency department. Cochrane Database Syst Rev. 2014 May 28;(5):CD010909. doi: 10.1002/14651858.CD010909.pub2. PMID: 24865567.

[12] Skorodin MS, Tenholder MF, Yetter B, Owen KA, Waller RF, Khandelwahl S, Maki K, Rohail T, D'Alfonso N. Magnesium sulfate in exacerbations of chronic obstructive pulmonary disease. Arch Intern Med. 1995 Mar 13;155(5):496-500. PMID: 7864705.
[13] Mukerji S, Shahpuri B, Clayton-Smith B, Smith N, Armstrong P, Hardy M, Marchant G, Marsh E. Intravenous magnesium sulphate as an adjuvant therapy in acute exacerbations of chronic obstructive pulmonary disease: a single centre, randomised, double-blinded, parallel group, placebo-controlled trial: a pilot study. N Z Med J. 2015 Nov 20;128(1425):34-42. PMID: 26905985.

[14] Edwards L, Shirtcliffe P, Wadsworth K, Healy B, Jefferies S, Weatherall M, Beasley R; Magnesium COPD Study Team. Use of nebulised magnesium sulphate as an adjuvant in the treatment of acute exacerbations of COPD in adults: a randomised double-blind placebo-controlled trial. Thorax. 2013 Apr;68(4):338-43. doi: 10.1136/thoraxjnl2012-202225. Epub 2013 Jan 7. PMID: 23299960.

[15] Song W. and Chang Y., 2012. Magnesium sulfate for acute asthma in adults: a systematic literature review. Asia Pacific Allergy, 2(1), p.76.

[16] Sterne JAC, Savović J, Page MJ, et al. RoB 2: a revised tool for assessing the risk of bias in randomised trials. BMJ 2019; 366: 14898 .

[17] Review Manager Web (RevMan Web). The Cochrane Collaboration; 2019. Available from: http: revman.cochrane.org. [Last accessed on 2020 Apr 01].

[18] Cochrane Handbook for Systematic Reviews of Interventions. 2008;

[19] Moher D, Liberati A, Tetzlaff J, Altman DG, PRISMA Group. Preferred reporting items for systematic reviews and meta-analyses: The PRISMA statement. J Clin Epidemiol 2009;62:1006-12.

[20] Nouira S, Bouida W, Grissa MH, Beltaief K, Trimech MN, Boubaker H, Marghli S, Letaief M, Boukef R. Magnesium sulfate versus ipratropium bromide in chronic obstructive pulmonary disease exacerbation: a randomised trial. Am J Ther. 2014 May-Jun;21(3):152-8. doi: 10.1097/MJT.0b013e3182459a8e. PMID: 22407196.

[21] Green RH. Asthma in adults (acute): magnesium sulfate treatment. BMJ Clin Evid. 2016 Jan 13;2016:1513. PMID: 26761432; PMCID: PMC4711892. 
[22] Irazuzta JE, Chiriboga N. Magnesium sulfate infusion for acute asthma in the emergency department. J Pediatr (Rio J). 2017 Nov-Dec;93 Suppl 1:19-25. doi: 10.1016/j.jped.2017.06.002. Epub 2017 Jul 26. PMID: 28754601.

[23] Shivanthan, M. C., \& Rajapakse, S. (2014). Magnesium for acute exacerbation of chronic obstructive pulmonary disease: A systematic review of randomised trials. Annals of thoracic medicine, 9(2), 77-80. https://doi.org/10.4103/1817-1737.128844

[24] Bhatt SP, Khandelwal P, Nanda S, Stoltzfus JC, Fioravanti GT. Serum magnesium is an independent predictor of frequent readmissions due to acute exacerbation of chronic obstructive pulmonary disease. Respir Med. 2008 Jul;102(7):999-1003. doi: 10.1016/j.rmed.2008.02.010. Epub 2008 Apr 8. PMID: 18396393.

[25] Solooki M, Miri M, Mokhtari M, Valai M, Sistanizad M, Kouchek M. Magnesium Sulfate in Exacerbations of COPD in Patients Admitted to Internal Medicine Ward. Iran J Pharm Res. 2014 Fall;13(4):1235-9. PMID: 25587312; PMCID: PMC4232789.

[26] do Amaral AF, Rodrigues-Júnior AL, Terra Filho J, Vannucchi H, Martinez JA. Effects of acute magnesium loading on pulmonary function of stable COPD patients. Med Sci Monit. 2008 Oct;14(10):CR524-9. PMID: 18830192.

[27] Kilıc H, Kanbay A, Karalezlı A, Babaoglu E, Hasanoglu HC, Erel O, Ates C. The Relationship between Hypomagnesemia and Pulmonary Function Tests in Patients with Chronic Asthma. Med Princ Pract. 2018;27(2):139-144. doi: 10.1159/000487760. Epub 2018 Feb 18. PMID: 29455196 ; PMCID: PMC5968247. 